\title{
Implementasi Cell ID Dan GPS Dalam Pencarian Lokasi Fasilitas Kesehatan Terdekat
}

\author{
Fahmi Candra Permana ${ }^{1}$, Diah Chaerani ${ }^{2}$, Erick Paulus ${ }^{3}$
}

${ }^{1}$ Prodi Teknik Telekomunikasi, Fakultas Teknik Elektro, Universitas Telkom

Jl. Telekomunikasi No. 01, Terusan Buah Batu, Sukapura, Dayeuhkolot, Bandung Email : fahmicandrap@gmail.com

${ }^{2}$ Departemen Matematika, Fakultas MIPA, Universitas Padjadjaran

Jl. Raya Bandung-Sumedang Km 21 Jatinangor, Sumedang

Email : d_chaerani@unpad.ac.id

${ }^{3}$ Departemen Ilmu Komputer, Fakultas MIPA, Universitas Padjadjaran

Jl. Raya Bandung-Sumedang Km 21 Jatinangor, Sumedang

Email : erick.paulus@unpad.ac.id

\begin{abstract}
Abstrak
Cell ID dan GPS merupakan layanan berbasis lokasi dan teknologi yang banyak membantu manusia dalam hal navigasi dan penemuan tempat-tempat yang bermanfaat di sekitarnya. Salah satu komponen utama dari teknologi ini dapat diterapkan pada telepon seluler. Dalam penelitian ini, dirancang sebuah aplikasi dengan memanfaatkan teknologi berdasar implementasi dari Cell ID dan GPS untuk mengetahui posisi user dan lokasi fasilitas kesehatan terdekat di sekitar user dan penggunaan JSON sebagai sarana untuk menyimpan data berbasis web database. Aplikasi ini diimplementasikan pada telepon seluler dengan sistem operasi Android. Hasil dari penelitian ini menunjukkan bahwa Cell ID dan GPS dapat diimplementasikan dengan baik dengan memanfaatkan akses Internet dan Google Maps untuk mencari fasilitas kesehatan terdekat dan menggambarkan daerah sekitar user.
\end{abstract}

Kata kunci: Cell ID, GPS, telepon seluler, Android, Google Maps, JSON

\begin{abstract}
Cell ID and GPS is a location-based services and technologies that helped peoples in terms of navigation and discovery of useful places in the vicinity. One of main component of this technology can be applied to mobile phones. In this study, we design a technology-based application utilizing the implementation of Cell ID and GPS to determine the user's position and location of the nearest medical facilities around the user and using JSON as a media to store the database on the web. This application is implemented on a mobile phone with Android operating system. The result of this study shows that the Cell ID and GPS can be implemented using Internet access and Google Maps to find the nearest health facilities and describes the area around them.
\end{abstract}

Keywords:Cell ID, GPS, mobile phone, Android, Google Maps, JSON

2000 Mathematics Subject Classification:

Received: 04-04-2017, accepted: 26-05-2017. 


\section{Latar Belakang Masalah}

Dalam kehidupan masyarakat saat ini sering terjadi jika dalam satu kota besar terdapat banyak fasilitas kesehatan yang tersebar di berbagai daerah dalam kota tersebut. Ketika masyarakat membutuhkan informasi untuk mengetahui keberadaan fasilitas kesehatan tersebut, sehingga diperlukan suatu peta yang menunjukkan lokasi sebuah fasilitas kesehatan terdekat. Sangat merepotkan bila harus membuka peta berbentuk kertas hanya untuk mencari sebuah lokasi. Pemanfaatan Cell ID (Celullar Identity) dan GPS (Global Positioning System) sangat bermanfaat dalam kondisi tersebut karena dapat menunjukkan keberadaan suatu tempat atau lokasi. Cell ID dan GPS merupakan media/alat yang dapat berfungsi sebagai layanan informasi yang dapat diakses melalui perangkat mobile melalui jaringan Internet serta memanfaatkan kemampuan penunjuk lokasi.

Seiring dengan diikuti berkembangnya teknologi, sebuah telepon seluler tidak hanya sebagai alat komunikasi saja, tetapi dilengkapi juga dengan berbagai fitur tambahan yang mendukung aktifitas penggunanya. Berbagai fitur seperti e-mail, browsing, internet, Cell ID dan GPS sudah banyak dimiliki oleh sebuah telepon seluler. Fitur Cell ID dan GPS pada telepon seluler dapat digunakan untuk memperoleh informasi lokasi yang diinginkan oleh pengguna. Sehingga pengguna telepon seluler dapat mengakses keberadaan lokasi mereka untuk mengetahui letak fasilitas kesehatan terdekat dengan memanfaatkan Cell ID ataupun GPS dari telepon seluler.

Hingga saat ini telepon seluler dengan sistem operasi android merupakan ponsel dengan hasil penjualan terbanyak dibanding ponsel dengan sistem operasi yang lain. Untuk memenuhi kebutuhan mayoritas pengguna telepon seluler, dalam penelitian ini dirancang sebuah aplikasi berbasis sistem operasi Android. Gambar 1 yang menunjukan persentase penjualan telepon seluler dengan sistem operasi android dibanding telepon seluler dengan sistem operasi lain di tahun 2014.

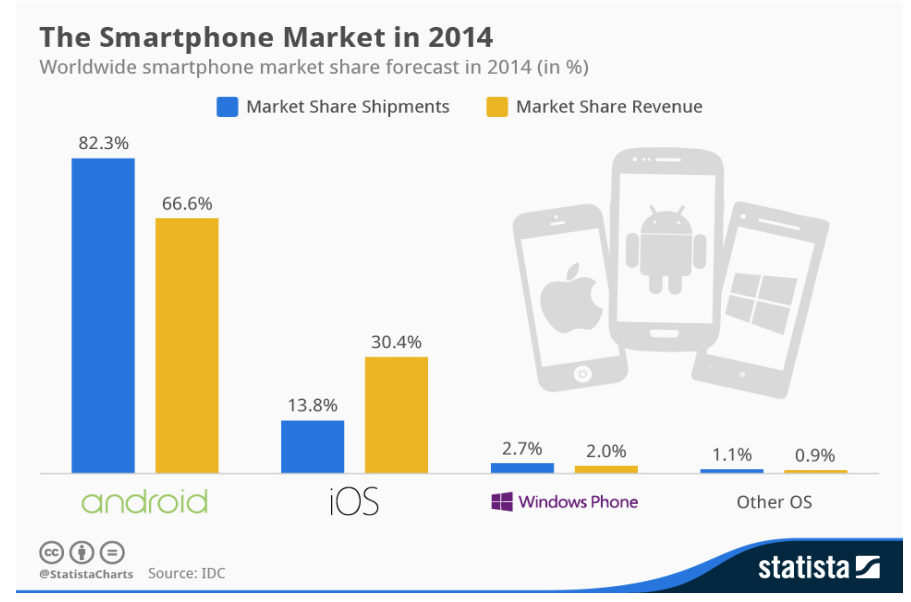

Gambar 1. Penjualan telepon seluler berdasakan sistem operasi [12]

Berikut ini adalah beberapa penelitian tentang Implementasi Cell ID dan GPS dalam pencarian Lokasi : Aprilia Rachmawati, pada tahun 2011, dalam papernya yang berjudul Pencarian Lokasi Fasilitas Umum Terdekat Pada Perangkat Mobile Dengan Penentuan Posisi User Menggunakan Cell ID, membuat program pencarian fasilitas umum terdekat di sekitar kota Surabaya. X. Wang, A. K. s. Wong dan Y. Kong, dalam papernya yang berjudul "Mobility tracking using GPS, Wi-Fi and Cell ID," pada tahun 2012 membuat kompilasi pendeteksian lokasi secara akurat berdasarkan Cell ID, GPS, dan Wi-Fi yang digunakan pengguna telepon seluler. Kemudian X. Delman, Z. Shibeshi dan M. Scott, dalam papernya yang berjudul "Development of a Location Based Service for Technician Allocation" pada tahun 2016 membuat 
sebuah aplikasi berbasis lokasi untuk mengalokasikan teknisi suatu perusahaan dalam menangani keluhan pelanggan di suatu daerah berdasarkan banyaknya keluahan dari pelanggan.

\section{TINJAUAN PUSTAKA}

2.1. Cell ID. Cell ID adalah nomor unik yang umumnya digunakan untuk mengidentifikasi setiap Base Transceiver Station (BTS) dalam jaringan GSM atau dalam Location Area Code (LAC). Sebuah penyedia jaringan memiliki beberapa ratus BTS (sel) yang membentuk jaringan. Setiap base station adalah "sel" yang mencakup wilayah fisik dan sel-sel ini terhubung bersamasama untuk membuat seluruh jaringan. Jarak sel tergantung pada kepadatan base station yang dipasang di daerah tertentu. Jarak sel dapat bervariasi mulai dari $100 \mathrm{~m}$ di kota-kota hingga $3 \mathrm{KM}$ di daerah pedesaan. Cell ID tidak seakurat beberapa teknik lainnya, karena cakupan sel tidak tetap. Keuntungan dari menggunakan Cell ID adalah tidak ada ponsel khusus yang dibutuhkan, dan layanan ini gratis [2].

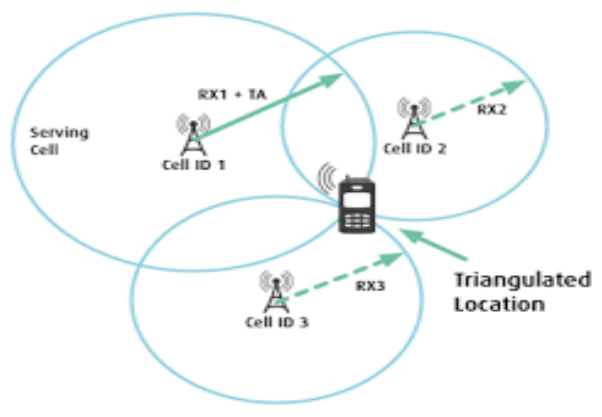

Gambar 2. Daerah cakupan sinyal menggunakan Cell ID [13]

2.2. GPS (Global Positioning System). Global Positioning System adalah suatu sistem navigasi yang menggunakan satelit dan komputer untuk menentukan posisi lintang dan bujur dari suatu client dengan cara melakukan komputasi terhadap perbedaan waktu sampainya sinyal dari beberapa satelit yang berbeda ke user [3].

2.3. Mobile Google Maps. Mobile Google Maps (MGMaps) merupakan sebuah aplikasi freeware yang dapat digunakan untuk menampilkan peta dari Google Maps, Yahoo! Maps, Open Street Map, dan beberapa sumber peta lain pada perangkat mobile yang mendukung J2ME. MGMaps juga dapat disimpan dalam kartu memori untuk dipergunakan secara offline [3]. Secara teknis, MGMaps memiliki fungsionalitas penuh dalam hal pemetaan mobile di antaranya:

(1) Peta Interaktif, yang berarti kemandirian sumber peta, mendukung lebih banyak standar vendor API, dan mendukung Web Map Service (WMS).

(2) Layanan penunjuk arah. Merupakan cara tercepat menghitung jarak dan menentukan rute antara dua titik.

(3) Layanan geocoding. Dapat menemukan nama-nama lokasi dan tempat menarik.

(4) API location. Menemukan lokasi pengguna dengan metode penentuan posisi. Sebagai contoh, perangkat GPS melalui Bluetooth atau menggunakan GPS internal.

2.4. API Key. API Key merupakan sebuah kode unik yang digunakan untuk mendapatkan fasilitas dari Google Maps. Untuk menggunakan Google Maps terdapat beberapa mekanisme pendaftaran yang disediakan oleh Google untuk mendapatkan sebuah identitas (API Key). Pada proses pendaftaran tersebut juga memerlukan kunci yang akan dihasilkan secara otomatis ketika komputer terinstalasi SDK Android [3]. Setelah mendapatkan API Key, maka Google Maps dapat digunakan untuk menampilkan peta yang akan digunakan. 
2.5. Android. Android merupakan subset perangkat lunak untuk perangkat mobile yang meliputi sistem operasi, middleware dan aplikasi inti yang dirilis oleh Google. Sedangkan Android SDK (Software Development Kit) menyediakan tools dan API (Application Programming Interface) yang diperlukan untuk mengembangkan aplikasi pada platform Android dengan menggunakan bahasa pemrograman Java [7]. Google sebagai pengembang Android sebagai sistem operasi untuk perangkat seluler memberikan kode projek untuk setiap versi dari Android. Pemberian nama tersebut berdasarkan abjad jenis makanan penutup. Adapun versi Android antara lain :

(1) Android versi 1.1

(2) Android versi 1.5 (Cup Cake)

(3) Android versi 1.6 (Donut)

(4) Android versi 2.1 (Eclair)

(5) Android versi 2.2 (Frozen Yoghurt)

(6) Android versi 2.3 (Gingerbread)

(7) Android versi 3.0 (Honeycomb)

(8) Android versi 4.0 (Ice Cream Sandwich)

(9) Android versi 4.1 (Jelly Bean)

(10) Android versi 4.4 (KitKat)

(11) Android versi 5.0 (Lollipop)

(12) Android versi 6.0 (Marshmallow)

2.6. Bahasa Pemrograman Java. Bahasa Pemrograman Java adalah sebuah bahasa pemrograman komputer berbasiskan kepada Object Oriented Programming (OOP). Java diciptakan setelah $\mathrm{C}++$ dan didesain sedemikian sehingga ukurannya kecil, dan sederhana. Program yang dihasilkan dengan bahasa Java dapat berupa applet (aplikasi kecil yang jalan di atas web browser) maupun berupa aplikasi mandiri yang dijalankan dengan program Java Interpreter. Contoh program yang ditulis dengan bahasa Java adalah HotJava yang berupa sebuah web browser [9].

Java bersifat netral, tidak bergantung pada suatu platform dan mengikuti prinsip WORA (Write Once and Run Anywhere). Beberapa bahasa pemrograman seperti Basic, Fotran, Pascal, COBOL, C, ProLog, dan yang lainnya harus bergantung pada suatu platform karena mengharuskan mengkompilasi program pada setiap sistem operasi yang ditentukan, jika ingin menggunakan hasil program tersebut [9].

2.7. Eclipse. Eclipse merupakan sebuah Integrated Development Environment (IDE) untuk mengembangkan perangkat lunak dan dapat dijalankan di semua platform. Eclipse pada saat ini merupakan IDE paling diminati karena gratis dan bersifat open source, yang berarti setiap orang boleh melihat kode pemrograman perangkat lunak ini. Selain itu, kelebihan dari Eclipse yang membuatnya populer adalah kemampuannya untuk dapat dikembangkan oleh pengguna dengan komponen yang dinamakan plug-in [10].

2.8. JSON. JSON (JavaScript Object Notation) adalah format pertukaran data yang ringan, mudah dibaca dan ditulis oleh manusia, serta mudah diterjemahkan dan dibuat (generate) oleh komputer. Format ini dibuat berdasarkan bagian dari Bahasa Pemprograman JavaScript, Standar ECMA-262 Edisi ke-3 - Desember 1999. JSON merupakan format teks yang tidak bergantung pada bahasa pemprograman apapun karena menggunakan gaya bahasa yang umum digunakan oleh programmer keluarga C termasuk C, C++, Java, JavaScript, Perl, Python dll. Oleh karena sifat-sifat tersebut, menjadikan JSON ideal sebagai bahasa pertukaran-data. JSON terbuat dari dua struktur:

(1) Kumpulan pasangan nama/nilai. Pada beberapa bahasa, hal ini dinyatakan sebagai objek (object), rekaman (record), struktur (struct), kamus (dictionary), tabel hash (hash table), daftar berkunci (keyed list), atau associative array.

(2) Daftar nilai terurutkan (an ordered list of values). Pada kebanyakan bahasa, hal ini dinyatakan sebagai larik (array), vektor (vector), daftar (list), atau urutan (sequence). 
Struktur-struktur data ini disebut sebagai struktur data universal. Pada dasarnya, semua bahasa pemprograman modern mendukung struktur data ini dalam bentuk yang sama maupun berlainan. Hal ini pantas disebut demikian karena format data mudah dipertukarkan dengan bahasa-bahasa pemrograman yang juga berdasarkan pada struktur data ini [11].

2.9. Stratified Random Sampling. Stratified Random Sampling dapat diartikan sebagai proses pengambilan sampel dari populasi yang bersifat heterogen yang kemudian dipilah-pilah ke dalam sub populasi yang bersifat homogen yang disebut strata dan selanjutnya dari setiap strata tersebut dipilih satuan pengamatan secara random [5]. Prosedur penggunaan Stratified Random Sampling adalah sebagai berikut, pertama, peneliti membagi populasi kedalam beberapa sub poplasi atau strata berdasarkan informasi yang didapat. Kedua, peneliti merumuskan sampling frame pada masing-masing sub populasi atau strata. Ketiga, peneliti memilih sampel pada masing-masing sub populasi atau strata dengan menggunakan sample random atau systematic sampling [5].

\section{ANALISIS DAN PERANCANGAN}

3.1. Analisis Kebutuhan. Untuk memberikan gambaran umum kepada pengguna tentang sistem baru yang akan dibuat maka sebuah sistem perlu dianalisis. Dengan demikian, dapat diketahui keunggulan dan kelemahan sebuah sistem yang akan dijadikan acuan untuk evaluasi terhadap sistem tersebut. Penelitian ini disusun untuk menganalisis tentang tahapan dan membangun suatu aplikasi untuk mengetahui posisi fasilitas kesehatan dengan jarak terdekat dari posisi keberdaan user. Untuk membuat aplikasi Cari Fasilitas Kesehatan, aplikasi tersebut harus terintegrasi dengan sebuah peta yang menggambarkan keadaan sebenarnya dari sebuah daerah. Dengan ditampilkannya sebuah peta, sehingga memudahkan pengguna untuk mengetahui letak Fasilitas Kesehatan yang ingin dituju, bahkan di tempat yang tidak dikenali. Selain adanya peta, aplikasi tersebut harus memiliki akses Internet untuk mendapatkan letak keberadaan pengguna aplikasi dan daftar fasilitas kesehatan yang tersimpan dalam database web. Selain kebutuhan yang telah dijelaskan sebelumnya, aplikasi tersebut juga dibangun berdasarkan kebutuhan-kebutuhan sebagai berikut :

(1) Mampu mengetahui keberadaan fasilitas kesehatan terdekat.

(2) Dapat memberikan rute terpendek untuk mencapai fasilitas kesehatan terdekat.

(3) Dapat dijalankan pada Android versi versi 4.4 (Kitkat).

3.2. Rancangan Aplikasi Cari Fasilitas Kesehatan. Pada tahap ini, dijelaskan rancangan dari sebuah sistem yang diterapkan pada aplikasi pencarian fasilitas kesehatan terdekat dengan pemanfaatan berdasar dari implementsi Cell ID dan GPS pada sistem operasi Android. Gambar 3 menunjukan kerja sistem tersebut.

Berdasarkan Gambar 3 dapat dijelaskan sistem kerja dari Aplikasi, yaitu :

(1) Pengguna melakukan pencarian lokasi keberadaannya dengan melakukan permintaan kepada Cell ID dan atau GPS.

(2) Cell ID dan atau GPS memberikan informasi tentang keberadaan pengguna dengan memberikan titik koordinat.

(3) Hasil yang diterima dari Cell ID dan atau GPS dikirim ke Google Maps dan database lokasi melalui jaringan komunikasi dan Internet.

(4) Google Maps menerima koordinat lokasi yang didapat dari database lokasi yang tersimpan.

(5) Setelah mendapatkan koordinat lokasi, google Maps mengirimkan kembali hasil tersebut langsung kepada pengguna beserta rute yang diperlukan.

3.3. Pencarian Rute Tujuan. Google Maps API memberikan beberapa fungsi untuk mendapatkan rute tependek dari beberapa lokasi yang sudah ditentukan. Fungsi tersebut sudah termasuk dalam satu paket dan hanya tinggal menggunakannya. Tahap ini terjadi ketika pengguna menekan tombol untuk menentukan rute dari beberapa lokasi yang sudah ditentukan 


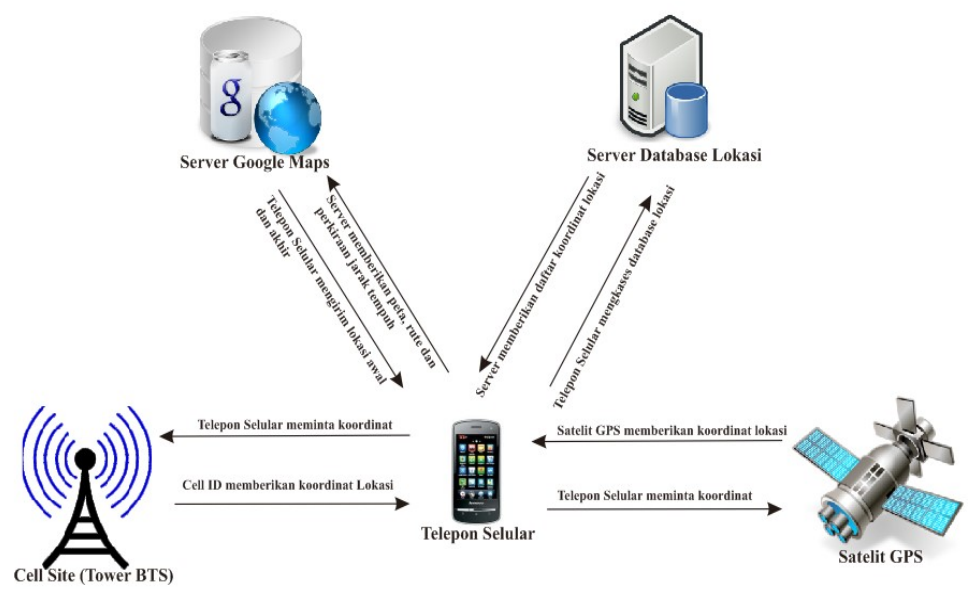

Gambar 3. Rancangan Aplikasi dengan Implementasi Cell ID dan GPS

sebelumnya. Pada tahap ini, dilakukan inisialisasi parameter-parameter yang akan digunakan sesuai dengan keinginan pengguna.

Pada Gambar 4 dapat dilihat terdapat beberapa kondisi yang dapat dipilih oleh pengguna dalam menampilkan jalur terpendek. Berikut penjelasan Gambar 4 :

(1) Setelah user memulai aplikasi akan tampil peta dan fasilitas kesehatan.

(2) User memilih fasilitas kesehatan yang dituju.

(3) User memilih posisi awal yang digunakan, bisa dengan menggunakan Cell ID dan atau GPS ataupun memilih posisi awal sendiri dalam peta.

(4) User memilih pencarian rute, bisa menggunakan mobil pribadi, angkutan umum, ataupun berjalan kaki.

(5) User mendapatkan rute tercepat yang telah diberikan oleh Google Maps.

3.4. Perancangan Data Lokasi Fasilitas Kesehatan. Dalam pembuatan aplikasi ini, data yang digunakan untuk menampung titik koordinat fasilitas kesehatan disimpan dalam sebuah database web yang bisa diakses dengan bantuan syntax JSON dan file.php sebagai media penghubung ke database. Data lokasi fasilitas kesehatan terdiri dari tiga tabel. Gambar 5 berikut menunjukkan tabel-tabel yang akan digunakan :

\section{HASIL DAN PEMBAHASAN}

4.1. Implementasi Sistem. Aplikasi Cari Fasilitas Kesehatan dirancang untuk mendapatkan posisi user dan fasilitas kesehatan berdasarkan lokasi keduanya secara real-time. Pada implementasinya diperlukan akses Internet untuk mengakses Cell ID dan google maps pada telepon seluler dan atau GPS yang terintegrasi dengan telepon seluler. Untuk dapat menggunakan akses Internet dan GPS pada telepon seluler, diperlukan sebuah permission yang ditujukan kepada telepon seluler agar dapat menggunakan akses Internet dan fitur GPS. Berikut ini merupakan potongan source code agar sistem dapat menggunakan akses Internet dan GPS.

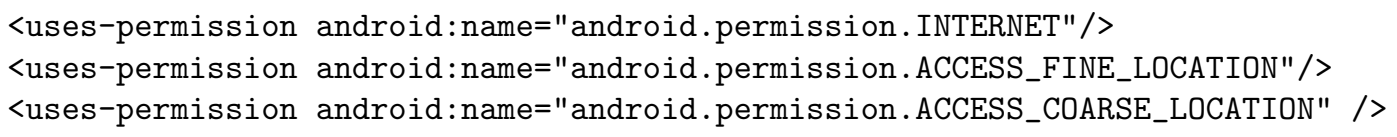

Seperti yang terlihat pada potongan source code di atas, akses Internet dan GPS dapat digunakan setelah meletakkan source code pada AndroidManifest.xml. ACCESS-FINE-LOCATION digunakan untuk mendapatkan posisi user berdasar dengan menggunakan akses GPS. Sedangkan ACCESS-COARSE-LOCATION digunakan untuk mendapatkan posisi user dengan metode Cell ID atau provider. 


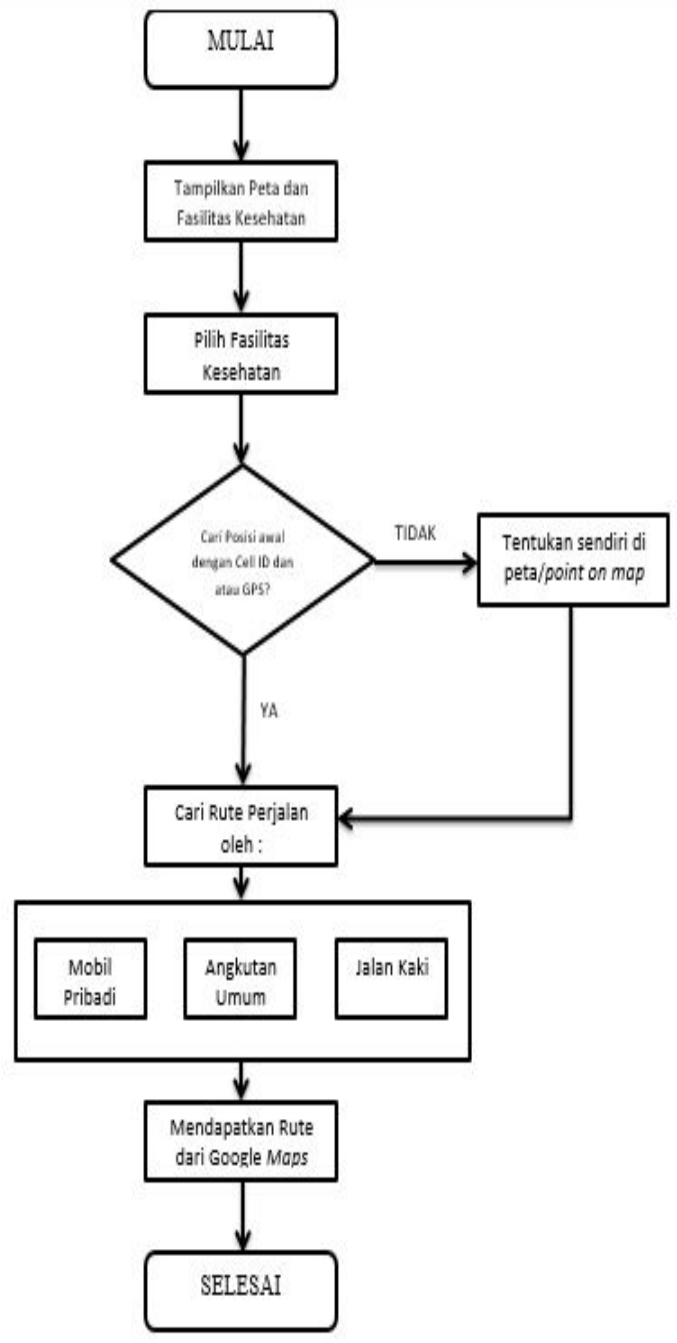

Gambar 4. Diagram Alir Tahap Pencarian Rute Tujuan

\begin{tabular}{|l|}
\hline Puskesampling \\
No* \\
NamaPuskesmas \\
Kecamatan \\
Latitude \\
Longitude \\
\hline
\end{tabular}

\begin{tabular}{|l|}
\hline Rumah_Sakit \\
\hline ID_RS* \\
Nama_RS \\
Alamat \\
Latitude \\
Longitude \\
\hline
\end{tabular}

Pelayanan

No*

jenis_pelayanan

sub

ID_RS

GAmBAR 5. Stuktur Data Lokasi Fasilitas Kesehatan

4.2. Implementasi Data Lokasi Fasilitas Kesehatan. Data lokasi Fasilitas Kesehatan dalam aplikasi ini merupakan hasil sampling pada data Fasilitas Kesehatan yang didapat dari Dinas Kesehatan Kota Bandung yang diletakkan pada database web: www.tugasakhirunpad.com -lu.com yang diakses saat aplikasi ini mulai dijalankan. Data lokasi failitas kesehatan ini terdiri dari tiga tabel, yaitu tabel rumah sakit, puskesampling dan tabel pelayanan. Tabel rumah sakit 
terdiri dari enam kolom, yaitu "ID","Nama-RS", "Telepon" , "Alamat", "Latitude", "Longitude". Untuk lebih jelasnya, dapat dilihat dari Gambar 6. Tabel selanjutnya adalah tabel

\begin{tabular}{|c|c|c|}
\hline Nama_RS & Alamat & Telepon Latitude Lon \\
\hline X 1 RSU Dr. Hasan Sadikin & J) Pasteur No 38 Bandung & $022203495-6.898319107 .598369$ \\
\hline ×2 RSUD Ujung Berung & I) Rumah Sakit No 22 Band & $022780001-6.915646107 .69891$ \\
\hline X3 RSU Sartika Asih & Jl Moch Toha No 369 Bandu & $022522954-6.956048107 .61235$ \\
\hline \& 4 RSU Sariningsih & Jl RE Martadinata No 9 Ba & $022420425-6.906574107 .610933$ \\
\hline × 5 RSU Dr. Salamun & I Ciumbuleuit No 203 Ban & $022203209-6.864652107 .605035$ \\
\hline $8 \times 6$ RSU Pindad & Jl Gatot Subroto PO BOX 8 & $022732796-6.939953107 .646365$ \\
\hline × 7 RSU Muhamma & Jl KH Ahmad Dahlan No 53 & $022730106-6.93339 \quad 107.623317$ \\
\hline × 8 RSU Al-Islam & Jl Sukarno Hatta No 644 B & $022756558-6.939364107 .669073$ \\
\hline × 9 RSU St. Borromeus & Jl Ir H Juanda no 100 Ban & $022250404-6.8$ \\
\hline × 10 RSU Bungsu & Jl Veteran No 6 Bandung & $022423055-6.918553107 .613347$ \\
\hline X 11 RSU Rajawali & J| Rajawali no 38 Bandung & $022601113-6.912$ \\
\hline $\mathbf{X} 12$ RSU St. Yusuf & Jl Cikut & 02272 \\
\hline $\mathbf{X} 13$ RSU Immanuel & Jl Kopo No 161 Bandung & $022520165-6.935978107 .596699$ \\
\hline X 14 RSU Kebonjati & Jl Kebon Jati No 52 Bandu & $022603196-6.91$ \\
\hline X 15 RSU Advent & Jl Champelas No 161 Band & $022203438-6.8$ \\
\hline × 16 Sentosa Bandung & | J| Kebon Jati No 38 Bandu & $022423439-6.9$ \\
\hline X 17 RS Jiwa Bandung & Jl RE Martadinata No 11 B & $022420544-6.906$ \\
\hline X 18 RS Jiwa Hurip Walu & Jl Karang Tineung $1 \mathrm{~A}$ Ban & $022203889-6.8$ \\
\hline X 19 RS Mata Cicendo & Jl Cicendo No 4 Bandung & $022423128-6$ \\
\hline X 20 RSB Astanaanyar & Jl Astana Anyar NNo 224 Ba & $022520113-6.929244107 .600513$ \\
\hline X 21 RSTP Cipaganti & Jl Bukit Jarian No 40 Ban & $022203142-6.8$ \\
\hline × 22 RSB Limijati & J] RE Martadinata No 39 B & $022420777-6.90$ \\
\hline $\mathbf{X} 23$ RS Halmahera & Jl RE Martadinata No 28 B & $022420606-6.906531107 .615622$ \\
\hline X 24 RSIA Sukajadi & Jl Sukajadi № 149 bandun & $022203294-6.886579107 .596353$ \\
\hline X 25 RSB Emma P & Jl Sumatra No $46-48$ Bandu & $022420543-6.913279107 .613642$ \\
\hline X 26 RSB Ted & Jl RE Martadinata No 97 B & $022423413-6.905594107 .620131$ \\
\hline$\times 27$ RSK Ginja & Jl Tubagus Ismail No 97 B & $022250198-6.885258107 .619921$ \\
\hline
\end{tabular}

GAMBAR 6. Beberapa lokasi rumah sakit pada tabel rumah sakit

pelayanan yaitu tabel yang berisi jenis pelayanan dan sub pelayanan yang disediakan rumah sakit berdasar dari data yang diperoleh Dinas Kesehatan Kota Bandung dan nantinya dihubungkan dengan tabel rumah sakit terdiri dari empat kolom, yaitu "No", "jenis-pelayanan", "sub" , "ID-RS". Untuk lebih jelasnya, dapat dilihat dari Gambar 7 Untuk dapat mengakses

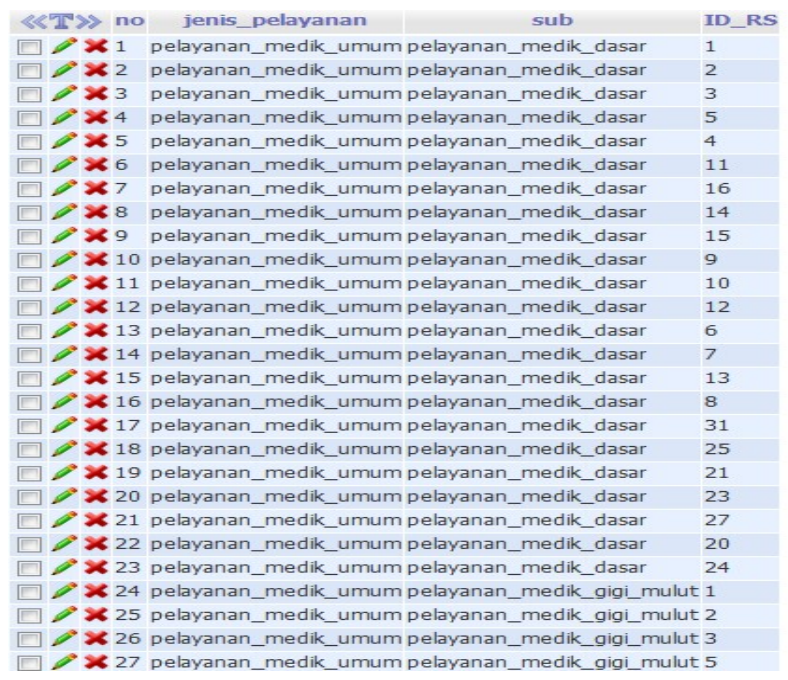

GAMBAR 7. Beberapa jenis pelayanan dan sub pelayanan pada tabel pelayanan 
database ini, sistem harus melakukan koneksi dengan database dan file .php agar setiap tabel dapat terhubung pada aplikasi ini. Sebagai contoh berikut ini potongan coding untuk koneksi ke database pada class LokasiFasKes.java.

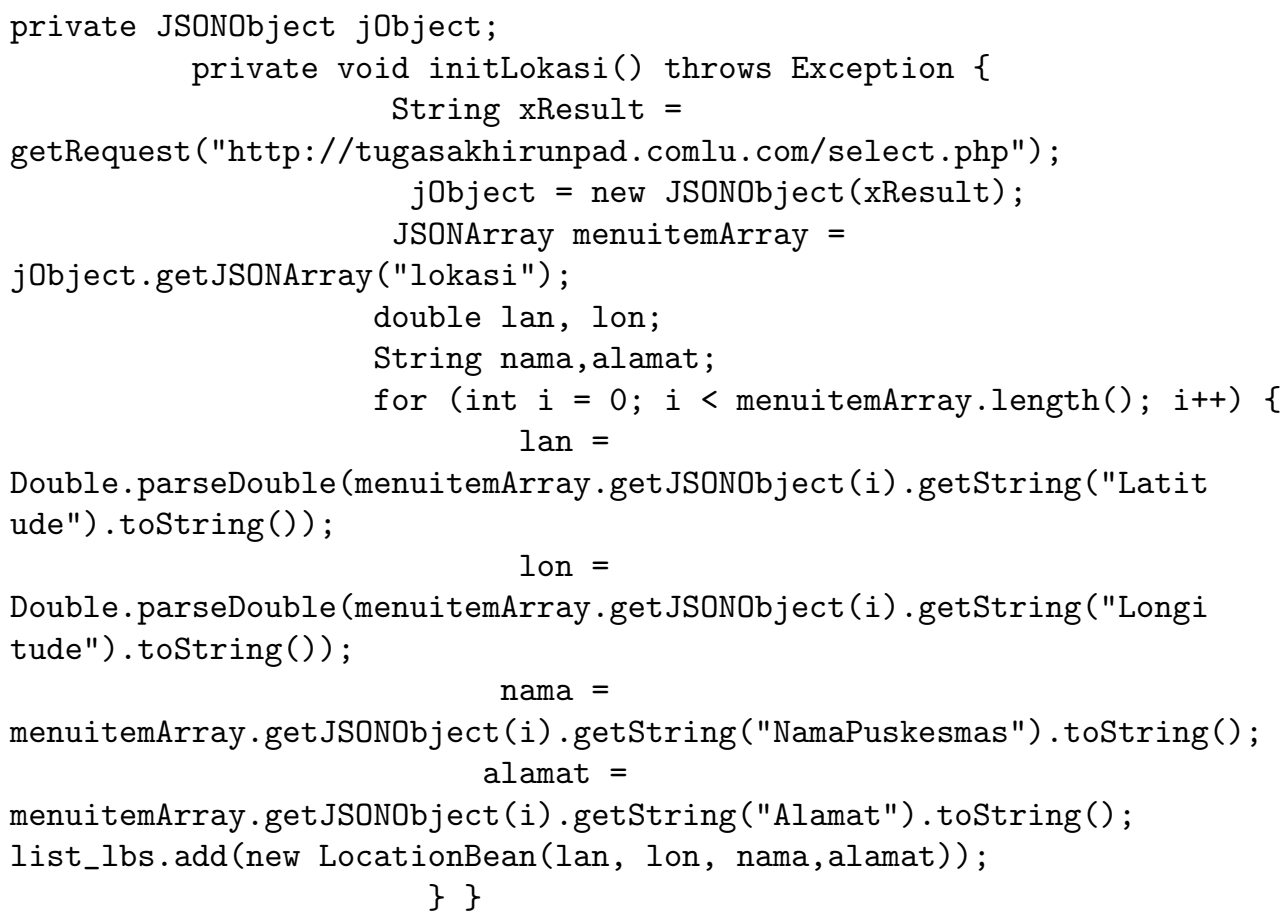

4.3. Gambaran Umum Sistem. Pada saat pertama user menggunakan aplikasi Cari Fasilitas Kesehatan, user akan memasuki form menu awal. Pada form menu awal terdapat beberapa tombol yang dapat dipilih untuk melakukan proses-proses lainnya. Tombol-tombol yang dapat dipilih di antaranya lokasi Peta Fasilitas Kesehatan, Daftar Pelayanan Fasilitas Kesehatan, dan button informasi. Untuk lebih jelasnya dapat dilihat pada Gambar 8 berikut. Pada saat user

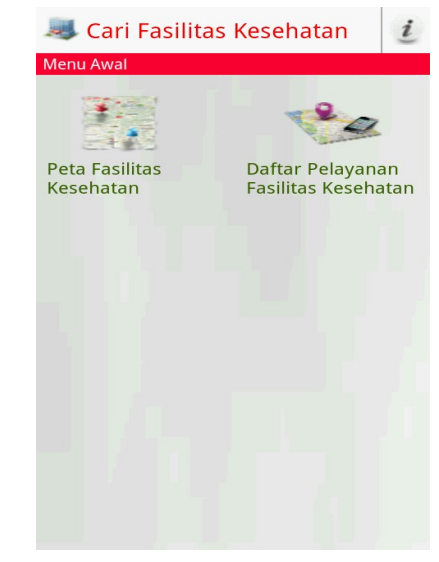

GAmbar 8. Form menu awal

memilih tombol Peta Fasilitas Kesehatan, maka user akan melihat posisi keberadaan user dan fasilitas kesehatan yang ada di sekitar user. Gambar 9 menunjukkan posisi keberadaan user saat menjalankan aplikasi Cari Fasilitas Kesehatan dan posisi fasilitas kesehatan yang berada di sekitar user. Pada Menu Peta Fasilitas Kesehatan, user dapat melihat posisi keberadaan user dan fasilitas kesehatan terdekat memerlukan waktu yang cukup lama, karena data lokasi terletak pada database web sehingga harus menunggu data dari database web terlebih dahulu. 


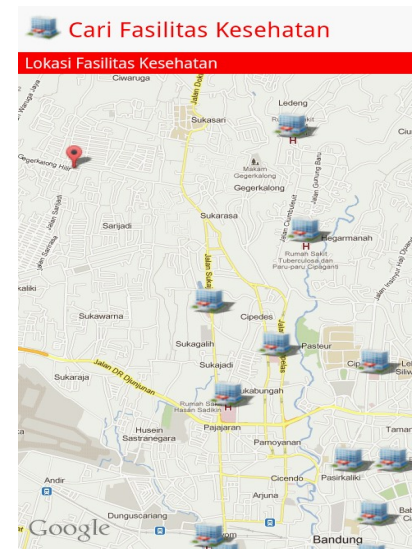

GAmBAR 9. Form lokasi user dan fasilitas kesehatan

4.4. Daftar Pelayanan Fasilitas Kesehatan. Pada aplikasi Cari Fasilitas Kesehatan, terdapat form menu yang berisi daftar pelayanan fasilitas kesehatan, fasilitas yang dimaksud pada menu ini adalah fasilitas yang tersedia di rumah sakit di Kota Bandung yang datanya penulis dapat dari Dinas Kesehatan Kota Bandung. Menu ini menampilkan daftar jenis pelayanan dan sub pelayanan kesehatan yang disediakan oleh rumah sakit di Kota Bandung. Gambar 10 menunjukkan form menu Daftar Pelayanan Fasilitas Kesehatan di Kota Bandung. Saat

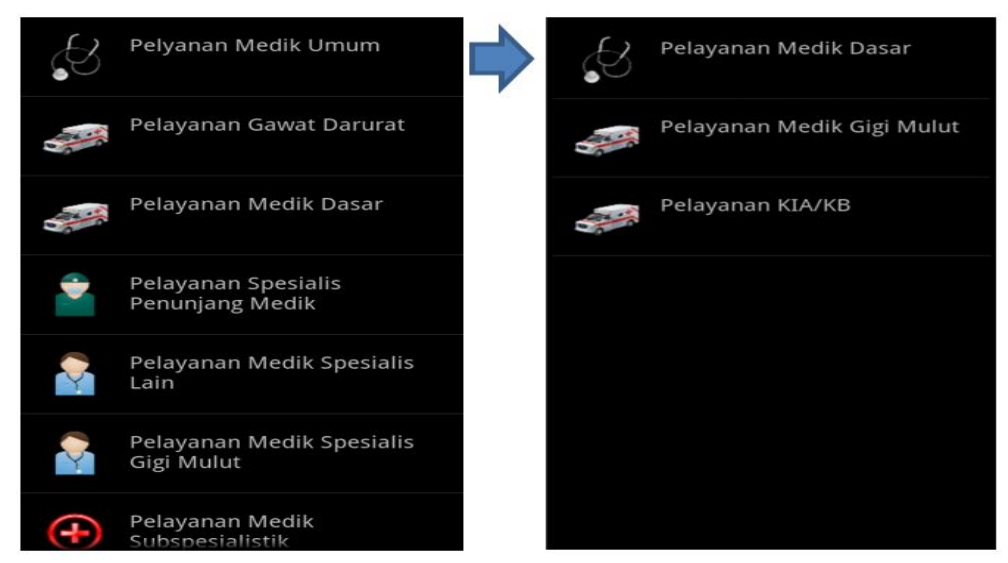

Gambar 10. Daftar jenis pelayanan dan sub pelayanan fasilitas kesehatan

user memilih salah satu dari jenis pelayanan fasilitas kesehatan, user harus melanjutkan sub pelayanan yang disediakan oleh rumah sakit, setelah itu akan muncul peta yang isinya rumah sakit yang menyediakan pelayanan yang telah dipilih oleh user.

4.5. Pencarian Rute Tercepat. Aplikasi Cari Fasilitas Kesehatan menyediakan informasi tentang jalur tercepat yang dapat ditempuh user berdasar fasilitas yang diberikan Google Maps, user dapat mendapatkan jalur tercepat untuk mencapai fasilitas kesehatan yang ingin dituju. Dengan memanfaatkan fitur intent, maka untuk mendapatkan jalur tempuh menuju lokasi fasilitas kesehatan dapat diperoleh dengan mudah.

Sebagai contoh, user berada di daerah ciseke besar dengan titik koordinat - -6.934734, 107.777359 ingin pergi menuju RSU Pindad yang berada dalam peta dengan titik koordinat -6.939953, 107.646365 dengan mengendarai mobil pribadi. Gambar 11 menunjukkan rute tercepat dan perkiraan waktu yang dapat ditempuh oleh user apabila ingin mencapai RSU Pindad dengan rute menggunakan mobil pribadi. 


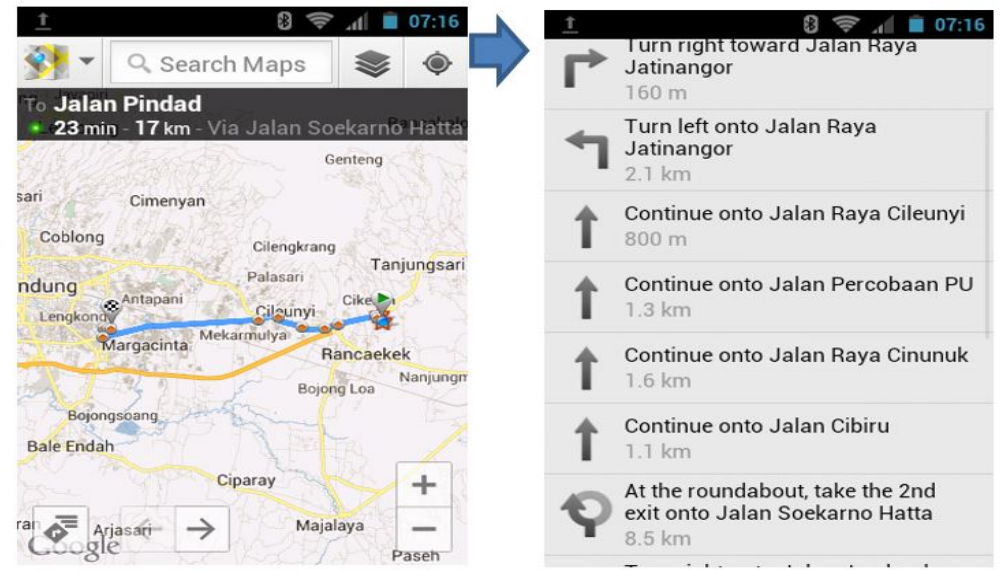

GAMBAR 11. Rute, jarak dan estimasi waktu menuju RSU Pindad dengan mengendarai mobil pribadi

\section{Kesimpulan}

Untuk membuat aplikasi Cari Fasilitas Kesehatan penulis menggunakan perangkat lunak Eclipse versi Hellios dengan bahasa pemrograman Java dan JSON (JavaScript Object Notation) sebagai penghubung database dari web ke aplikasi yang diimplementasikan pada telepon seluler yang menggunakan sistem operasi Android versi 4.4 (Kitkat). Aplikasi Cari Fasilitas Kesehatan bekerja pada telepon seluar dengan akses Internet untuk memperoleh data dan peta untuk menggambarkan daerah sekitar user, serta pemanfaatan Cell ID dan atau GPS untuk mendapatkan posisi user.

Posisi user dapat diketahui dengan menggunakan 2 metode yaitu menggunakan Cell ID dan atau GPS yang terintegrasi pada telepon seluler. Jarak fasilitas kesehatan dari user dapat ditentukan dengan mengetahui titik koordinat fasilitas kesehatan dan user. Sehingga dapat ditentukan fasilitas kesehatan mana yang terdekat dengan user dan rute perjalanan ke fasilitas kesehatan yang dituju dapat digambarkan sesuai dengan letak jalan yang ada pada Google Maps. Rute perjalanan yang didapat merupakan rute tercepat dari beberapa kemungkinan rute yang ada.

\section{DAFTAR PUSTAKA}

[1] X. Wang, A. K. s. Wong and Y. Kong, "Mobility tracking using GPS, Wi-Fi and Cell ID," The International Conference on Information Network 2012, Bali, 2012, pp. 171-176.

[2] Rachmawati, Aprilia. 2011. Pencarian Lokasi Fasilitas Umum Terdekat Pada Perangkat Mobile Dengan Penentuan Posisi user Menggunakan Cell ID . Surabaya : Teknik Informatika Institut Teknologi Sepuluh November.

[3] Andi. 2002. Global Positioning System (Gps) Overview. Yogyakarta : STMIK AMIKOM Yogyakarta.

[4] X. Delman, Z. Shibeshi and M. Scott, "Development of a Location Based Service for technician allocation," 2016 IST-Africa Week Conference, Durban, 2016, pp. 1-8.

[5] Sudjana, 2005. Metoda Statistika. Bandung: Penerbit Tarsito.

[6] Hermawan, Stephanus. 2011. Mudah Membuat Aplikasi Android. Yogyakarta : Penerbit Andi.

[7] Safaat, Nazruddin. 2011. Android Pemrograman Aplikasi Mobile Smartphone Dan Tablet PC Berbasis Android. Bandung : Informatika.

[8] Sholiq. 2006. Pemodelan Sistem Informasi Berorientasi Objek dengan UML. Yogyakarta : Graha Ilmu.

[9] Siallagan, Sariadin. 2009. Pemrograman Java Dasar-dasar Pengenalan Pemahaman. Yogyakarta : Penerbit Andi.

[10] http://eclipse.org/ (diakses pada tanggal 20 Mei 2015).

[11] http://www.json.org/json-id.html (diakses pada tanggal 9 September 2015).

[12] https://www.statista.com/chart/3014/smartphone-market-share-forecast/ (diakses pada tanggal 9 September 2015).

[13] https://forums.hak5.org/index.php?/topic/32404-triangulation/ 